\title{
EM DESTAQUE: A VISIBILIDADE FEMININA NA CAMPANHA “HIGHLIGHT THE REMARKABLE"
}

\author{
WOMEN'S VISIBLLITY STRESSED IN THE "HIGHLIGHT REMARKABLE CAMPAIGN"
}

\section{RESUMO}

Pensando em mulheres que foram imprescindíveis em vários momentos da história e não tiveram seu devido reconhecimento, a Stabilo - empresa alemã de canetas -, lançou a campanha "Highlight the Remarkable", onde destaca, em fotos antigas e com marca-texto, algumas mulheres, citando seus feitos que acabaram sendo evidenciados à outras pessoas ou omitidos na mídia. Então, o objetivo do artigo é analisar, do ponto de vista da linguagem publicitária, a campanha mencionada. Foram analisadas as mensagens literais, associadas e declaradas, utilizando-se de conceitos propostos por Barthes (2005). Em seu arcabouço teórico, a pesquisa teve diversos autores, como Kotler \& Keller (2013), Kotler et al (2010), Guillermo (2012), Bedendo (2015), Miguel \& Biroli (2014), Heywood (2010) e Tiburi (2018). Por fim, constata-se a importância de se debater sobre o feminismo e o papel da mulher, além de como as marcas podem contribuir na busca pelo espaço das mulheres na sociedade.

Palavras-chave: Marketing. Visibilidade Feminina. Feminismo. Campanha Publicitária.

\begin{abstract}
Thinking about women who were indispensable at various times in history and were not properly acknowledged, Stabilo launched the Highlight the Remarkable campaign, which highlights, in old photos, some women, citing their achievements that were not evident to the public or were omitted in the media. Thus, the purpose of the article is to analyze, from the point of view of advertising language, the mentioned campaign. We analyzed the literal, associated and declared messages, using concepts proposed by Barthes (2005). As a theoretical framework, we used several authors, such as Kotler \& Keller (2013), Kotler et al (2010), Guillermo (2012), Bedendo (2015), Miguel \& Biroli (2014), Heywood (2010) and Tiburi (2018). Finally, we noted the importance of discussing feminism and the role of women, as well as how brands can contribute to the search for women's place in society.
\end{abstract}

Keywords: Marketing. Female Visibility. Feminism. Advertising campaign.

Fernanda P. Bilhar

Universidade Feevale. Brasil. Email: febilhar@hotmail.com

Mauricio Barth

Universidade Feevale. Brasil. Email: mauricio@feevale.br

Débora Wissmann

Universidade Feevale. Brasil. Email: debora.w@feevale.br

Gustavo R. Sanfelice

Universidade Feevale. Brasil. Email: sanfeliceg@feevale.br 


\section{Introdução}

O universo midiático abrange uma série de diferentes plataformas que agem como meios para disseminar as informações, como os jornais, as revistas, a televisão, o rádio e a internet, por exemplo. A mídia, seja qual for, tem papéis fundamentais no desenvolvimento de um povo e, por conseguinte, da humanidade, principalmente em função da socialização da informação, da democratização do conhecimento e do direcionamento psicossocial. Nesse aspecto, não é de hoje que a invisibilidade feminina na sociedade vem sendo percebida, fato que sempre refletiu, também, na história e, por consequência, na mídia.

Dessa forma, pensando em mulheres que foram imprescindíveis em vários momentos da história e não tiveram seu devido reconhecimento, a Stabilo, marca alemã de canetas, lançou a campanha publicitária intitulada "Highlight the Remarkable". Nela são destacadas, em fotos antigas e com marca-texto, algumas mulheres mencionando seus feitos que acabaram sendo evidenciados à outras pessoas ou omitidos na mídia ${ }^{1}$. Destarte, o presente trabalho tem a seguinte problematização: como apresenta-se, do ponto de vista da linguagem publicitária, a campanha "Highlight the Remarkable", da Stabilo?

A pesquisa justifica-se, pois, a invisibilidade feminina na mídia é um assunto importante a ser debatido já que, ainda hoje, a mulher não tem a importância e o reconhecimento que merece, tendo sua imagem, na maioria das vezes, ligada aos estereótipos de gênero da publicidade e suas conquistas e opiniões ofuscadas. Objetiva-se, portanto, analisar, do ponto de vista da linguagem publicitária, a campanha "Highlight the Remarkable", da Stabilo. Especificamente, têm-se, ainda, o objetivo de: (a) descrever as peças selecionadas e (b) analisar nelas suas mensagens literais, associadas e declaradas.

\section{Marketing e posicionamento de marca}

Segundo Kotler \& Keller (2013), Marketing não se trata de vender produtos ou serviços, ele vem, inclusive, antes mesmo da criação deles, se trata sim de dar qualidade e valor, podendo competir além do preço. O interesse não é de que o cliente compre uma vez, mas sim de que esse crie uma relação com a marca e mantenha o seu interesse para consumir sempre. Essa é a forma que capta os clientes para a empresa e, apesar disso, ainda é um assunto mal interpretado e que não recebe sua devida importância. Para o marketing ter sucesso, é preciso ter conhecimento do mercado e público alvo, pois seu objetivo é criar e entregar o que esses necessitam, assim gerando um bom relacionamento com o cliente e o atendendo da melhor forma possível (KOTLER, 2003).

1 Disponível em: <https://www.b9.com.br/93552/Stabilo-chama-a-atencao-da-internet-com-propagandaque-marca-asmulheres-invisiveis-da-historia/?highlight=mulheres $>$. Acesso em: o1 jun. 2019. 
Para Kotler \& Keller (2013), toda a parte organizacional e financeira de uma empresa não tem sentido se não houver uma demanda que a faça vender e lucrar, e sem o marketing isso não é possível. A importância do marketing abrange toda a sociedade, pois é o que introduz e ajuda as pessoas a aceitarem novos produtos que podem inclusive facilitar suas vidas, além de observar quais as alterações que precisam ser feitas nos produtos já existentes para que o cliente se torne cada vez mais satisfeito e as empresas melhorem sua posição no mercado.

Segundo Kotler \& Keller (2013: 2), "O marketing de sucesso cria demanda para produtos, que, por sua vez, geram empregos. Ao contribuir com os resultados financeiros, o marketing bem-sucedido também possibilita à empresa se envolver mais em atividades socialmente responsáveis". Um dos conceitos essenciais do marketing envolve necessidades, desejos e demandas. As necessidades são tudo aquilo que o ser humano precisa para viver, exigências básicas que também podem se tornar desejos quando bem direcionados. Os desejos variam de acordo com a sociedade e com o ambiente em que o indivíduo vive.

Já a demanda é a vontade de possuir produtos específicos, não tão necessários, sustentados pelo preço que podem pagar. Segundo Kotler \& Keller (2013: 7), "O marketing não cria necessidades: as necessidades vêm antes dele. O marketing, juntamente a outros fatores sociais, influencia os desejos. Os profissionais de marketing podem, por exemplo, promover a ideia de que um Mercedes satisfaz a necessidade por status social. Contudo, eles não têm como criar a necessidade por status social". Como temos uma sociedade muito diferente, os gostos das pessoas também divergem muito, devendo ser levadas em conta as diferenças geográficas, psicográficas e comportamentais entre os clientes para traçar o perfil de grupo.

Os clientes estão cada vez mais exigentes e com fácil acesso à informação. Sendo assim, o marketing tem passado por diversas mudanças para se adaptar ao que o consumidor precisa, pois hoje o valor é determinado pelo cliente. Inicialmente era centrado no produto, posteriormente, passou a ser centrado no consumidor e hoje vemos o foco também nas questões humanas, o que é chamado de Marketing 3.o. Com a evolução da tecnologia interferindo diretamente no comportamento do consumidor, as redes sociais possibilitam que pessoas compartilhem opiniões e experiências, influenciando outros consumidores e diminuindo o impacto da propaganda corporativa no comportamento do consumidor. Além dessa mudança, a tecnologia estimula a globalização (KOTLER et al., 2010).

A globalização possui muitos paradoxos: o sociocultural em particular influencia não só países e empresas, afeta também as pessoas, fazendo com que tenham uma preocupação maior com a sociedade, passem a se conectar mais com a comunidade e tenham uma consciência maior dos efeitos do que consomem e apoiam no mundo. Por isso, as marcas culturais querem resolver os paradoxos da sociedade, para isso, precisam estar sempre atualizadas e entendendo o consumidor, além disso são consideradas marcas de grande valor. Mesmo as marcas culturais muitas vezes sendo vistas como estimulantes anti consumistas e contrárias às marcas globais, não significa que marcas globais não possam ser marcas culturais, principalmente se 
abordarem problemas que refletem na sociedade. O marketing 3.0 precisa entender os cidadãos globais e os problemas da sociedade referentes ao seu negócio (KOTLER et al., 2010).

Mas não só os consumidores podem usufruir da evolução da tecnologia, as empresas também podem utilizar a internet a seu favor. É mais uma forma de se obter informações sobre seu público alvo, mercado, concorrentes, etc. Além de possibilitar uma comunicação mais precisa, com diversas ferramentas de direcionamento e um amplo banco de dados, entregando anúncios e mensagens de acordo com os desejos e necessidades dos consumidores, ainda pode ser usada como canal de vendas e ampliar o alcance geográfico. Além disso, deve-se proporcionar um bom suporte, pois os clientes buscam não só adquirir o produto, mas também uma experiência (KOTLER \& KELLER, 2013).

Para estabelecer uma relação com os clientes, as marcas precisam criar um posicionamento, um DNA único que as diferencie. Esse DNA será sua cara nas redes sociais e comunicação com os consumidores e é também uma das maiores dificuldades para os profissionais de marketing. As empresas devem ser verdadeiras e transmitir isso ao seu público, não devem criar uma falsa realidade somente para a propaganda, pois isso é mal visto e acaba fazendo com que percam a credibilidade, ou seja, perdem seus compradores. (KOTLER et al., 2010).

Já não é mais suficiente para o cliente que o marketing seja focado somente no pensamento e no emocional, precisa se preocupar também com o espírito, isso deve ser incluído também na missão, visão e valores da empresa, traçando seu DNA corporativo. Através da missão deve-se transmitir o propósito pelo qual a empresa existe. Já a visão deve mostrar como a empresa deseja ser no futuro e o que pretende realizar. E os valores se tratam de comportamentos que as empresas adotam em sua gestão. Todos esses devem ser traçados pensando não somente em beneficiar a empresa, mas também os funcionários e consumidores. Segundo Kotler et al (2010: 49), "Embora seja essencial oferecer desempenho e satisfação ao cliente no nível de produto, no nível mais elevado, uma marca deve ser vista como algo que realiza as aspirações emocionais e pratica compaixão de alguma forma”. Sendo assim, o marketing deve ser uma junção de identidade, integridade e imagem. Não deve mais apenas ser considerado uma ferramenta de vendas e demandas, deve ser usado para construir uma relação e ter a confiança do consumidor. (KOTLER et al., 2010).

Descobrir como comunicar-se com o público alvo da maneira mais eficaz e atender às suas expectativas, tem se tornado cada vez mais uma tarefa desafiadora aos profissionais. Eles precisam utilizar meios de comunicação adequados, transmitir mensagens interessantes que valorizem a marca e fazer com que isso traga o resultado desejado, além de impulsionar as vendas da empresa. Pelo meio de comunicação e público ser diferente em todas essas áreas, pode-se imaginar que a comunicação a ser transmitida também deva ser, mas na verdade tudo gira em torno do consumidor final e da sociedade. Sendo assim, as informações que são entregues ao público formam a imagem da marca e seu brand equity. O público não identifica os diversos 
processos de comunicação e as divergências que possam existir (CRESCITELLI \& SHIMP, 2012).

Para promover o valor de uma marca, deve-se definir uma identidade positiva e criar associações positivas e fortes dela na mente do consumidor. Não é possível alcançar o brand equity somente com ações de marketing, a marca precisa ter garantias reais que possam sustentar a oferta. As marcas que querem ser reconhecidas pelo seu valor, precisam ter efetivamente boa qualidade, o valor dela não pode ser superficial. Uma imagem positiva não é criada de um dia para o outro, um trabalho de marketing contínuo é necessário para criar associações fortes e favoráveis sobre a marca (CRESCITELLI \& SHIMP, 2012).

A percepção da marca é baseada no fato de os consumidores lembrarem dela ou não quando falam de produtos que ela oferece, ou seja, é o quanto ela é conhecida. Porém, uma marca ser conhecida, não significa que ela possua valor ou que cause algum tipo de sentimento no consumidor, isso já tem muito mais a ver com o reconhecimento e recordação dela. Nesse sentido, o caminho que a comunicação de marketing deve seguir é: tornar a marca conhecida, buscar o reconhecimento e manter altos níveis de percepção de marca (o que deve continuar sendo trabalhado sempre), alcançar a recordação de marca e, por fim, a percepção top of mind, que significa que a marca é a primeira a ser lembrada quando os consumidores pensam a respeito de uma categoria ou produto específico (CRESCITELLI \& SHIMP, 2012).

Para Kotler \& Keller (2013), a marca deve estar sempre melhorando, com novidades de ofertas e marketing que sejam persuasivos. Quando um posicionamento é bem-sucedido, é muito improvável a necessidade de desviar-se dele. Mas ao longo do tempo, novas táticas podem ser necessárias para manter o engajamento e a direção estratégica da marca. Quando é necessário mudar, os profissionais de marketing devem evidenciar e manter aquilo que gera o brand equity.

Qualquer mudança no marketing pode afetar o sucesso de uma marca. Quando isso ocorre, é importante iniciar um processo de revitalização dessa marca. Relembrar as fontes originais de brand equity e alterar ou criar um novo posicionamento. Segundo Kotler \& Keller (2013: 164), “O desafio é mudar o suficiente para atrair novos clientes, mas não o bastante para deixar de lado os antigos. Praticamente todo tipo de revitalização de marca começa com o produto”.

A marca é uma das primeiras coisas a se pensar quando se inicia uma empresa, ou seja, deve-se pensar em um nome e um logotipo. Nem todos dão a importância necessária, mas conforme vão amadurecendo, percebem que precisam se esforçar para investir nessa parte e tratá-la com mais atenção. (GUILLERMO, 2012).

Há muito tempo as empresas começaram a entender a importância do valor de marca, nos últimos anos isso se intensificou ainda mais. Surgiram novas tecnologias e métodos de gestão, que estão cada vez mais avançados, principalmente quando se trata de entender o público e suas necessidades. Em consequência disso, as empresas têm contratado mais profissionais especializados para cuidar do branding. Não existe uma fórmula pronta quando se trata de criar valor de marca, pois lida-se com paixão, o que pode ser muito instável, mas também uma grande oportunidade 
para empreendedores, se souberem transmitir isso ao cliente com uma comunicação adequada (BEDENDO, 2015).

De acordo com Wheeler (2009: 14), "A identidade da marca alimenta o reconhecimento, amplia a diferenciação e torna grandes ideias e significados mais acessíveis". O branding é um processo que busca fazer com que as pessoas se conscientizem sobre a marca e tornem-se clientes fiéis, sempre aproveitando todas as oportunidades para destacar o diferencial e o porquê a marca deve ser a escolhida ao invés das outras (WHEELER, 2009).

Criar uma estratégia de marca é fundamental. É preciso planejar e desenvolver ações que chegarão ao objetivo traçado, isso engloba planejamento de marketing, mídia, comunicação, etc. Ou seja, deve envolver diversos profissionais de setores diferentes, todos devem trabalhar juntos e direcionados ao mesmo ponto. A estratégia de marca pode ser interessante para captar também acionistas e franqueados, pois preserva a identidade e mostra o potencial crescimento e planos futuros, o que mostra também que a empresa acredita na sua longevidade e gera confiança para que invistam na marca (GUILLERMO, 2012).

Para iniciar o posicionamento da marca, deve-se estudar e descobrir qual a necessidade ou desejo do consumidor, pois isso o possibilita criar um produto adequado e que atenda essa necessidade percebida. É preciso criar como diferencial algo que se destaque e comunicar de forma que esteja fortemente ligado a marca, não sendo necessariamente um benefício do produto em si, podendo ser também benefícios emocionais, funcionais ou de auto expressão. Os benefícios emocionais estão ligados às sensações que o consumidor tem ao utilizar o produto, o que faz com que eles se sintam mais seguros, as marcas que conseguem oferecer uma experiência e satisfazem o consumidor além do lado funcional, estão adicionando valor ao seu produto.

Os benefícios funcionais são básicos, o produto ou serviço deve oferecê-los. E mesmo a marca que esteja à frente da concorrência em outras funções, não deve esquecer da parte funcional, precisa entregar o que é esperado. Já os benefícios de auto expressão estão ligados a personalidade e estão cada vez mais sendo levados em consideração com a popularização das redes sociais. O consumidor utiliza a imagem da marca para se expressar, agregar isso a sua personalidade, sendo assim ele vai ter um envolvimento maior com a marca, pois ela representa o que ele quer transmitir. As marcas devem planejar como querem ser vistas para poderem alcançar o público que almejam (BEDENDO, 2015).

Para Wheeler (2009), posicionamento é a chave para criar vantagens em um mercado que está sempre mudando, encontrar oportunidades nessa variação é necessário para chamar atenção do seu público. A identidade de uma marca, é a sua "alma". É necessário adotar características e gerar um conteúdo que atraia o consumidor, que faça com que ele se identifique e sinta-se próximo da marca, que mostre como a marca quer ser percebida. Também é importante gerar relações (que podem ser afetadas por experiências do consumidor) e lembranças. Essas associações devem ser planejadas e controladas de acordo com o que a marca deseja transmitir e 
podem ser trabalhadas de diversas formas, sendo elas imagens, elementos, cheiros, cores, experiências, etc. (BEDENDO, 2015).

Para Guillermo (2012), cada vez mais estamos parecidos com os outros, então a identidade de marca é essencial para se destacar, mostrar sua singularidade e apresentá-la de uma forma que ninguém nunca viu. Mas ainda mais importante, é fazer isso de forma verdadeira e transparente. A marca pode mudar ou evoluir sua forma de comunicar para se adaptar ao que for preciso, alterando características e comportamentos, mas sempre mantendo seus valores e crenças alinhados, pois são uma questão de essência da marca (BEDENDO, 2015).

\section{Movimento feminista}

Segundo Miguel \& Biroli (2014: 18), "o pensamento feminista tornou-se o que é hoje: um corpo altamente elaborado de teorias e reflexões sobre o mundo social”. Desde sempre, a desigualdade de gênero é uma realidade no mundo inteiro, esse fato nunca foi algo oculto, pelo contrário, sempre foi tratado com muita normalidade, como se fosse natural e necessário devido à natureza diferenciada dos homens e das mulheres. Embora muito se ouça que isto já foi superado, devido a alguns avanços que já foram conquistados pelas mulheres, como acesso à educação, direito de voto e maior presença no mercado de trabalho, continuamos em uma sociedade desigual que segue desconsiderando que existe uma igualdade intelectual e moral e deixa as mulheres em desvantagem, sendo a conservação da dominação masculina ainda muito forte e notável (MIGUEL \& BIROLI, 2014).

O movimento feminista surgiu muito antes do que imaginamos, apesar do termo feminismo só se tornar habitual há pouco tempo atrás, é possível encontrar ideias feministas nas antigas civilizações, ainda que o movimento tenha começado a tomar força e ser melhor organizado em meados dos séculos XIX. O feminismo é constituído por duas ideias básicas: de que as mulheres vivem em desvantagem pelo simples fato de serem mulheres e de que essa desvantagem deve ser desfeita. Uma das maiores lutas foi a campanha pelo sufrágio feminino, ou seja, o direito de votar. As mulheres acreditavam que se tivessem direito ao voto, a discriminação e o preconceito sexual também acabariam. Esse período foi chamado de "primeira onda" e foi definido pela busca dos mesmos direitos legais e políticos que os homens já obtinham. A "primeira onda" teve fim quando o direito de voto foi conquistado e, ironicamente, o movimento feminista perdeu forças após o feito, pois acreditavase que haviam conquistado também a emancipação das mulheres. Após 1960, o movimento voltou a ter força e surgiu a "segunda onda", onde o objetivo era a "libertação da mulher", focada não somente em direitos legais e políticos, mas buscava uma mudança social, evidenciando questões pessoais, psicológicas e sexuais da opressão às mulheres (HEYWOOD, 2010). 
Até 1960, o feminismo era considerado apenas um subconjunto do liberalismo e do socialismo, e não uma ideologia. Essas eram as únicas ideologias que possuíam conceitos que poderiam ser aplicados também às questões de gênero. Com o feminismo radical ganhando força, esse conceito mudou, pois defendiam a importância política das divisões de gênero. Nenhuma ideologia concordava com isso, então estas passaram a ser vistas como inadequadas e até mesmo criticadas por possuir princípios patriarcais.

$\mathrm{O}$ feminismo possui diversas vertentes, as primeiras foram o feminismo radical, o feminismo liberal e o feminismo socialista, hoje já foram criadas diversas outras como o feminismo negro, feminismo pós-moderno, etc. Cada uma dessas vertentes acaba por ter muitas crenças diferentes, o que fez com que muitos enxergassem o movimento como um movimento de desacordo, mas apesar disso é possível identificar pontos importantes que estão presentes em todos os fragmentos, como: a separação entre o público e o privado; patriarcado; sexo e gênero; igualdade e diferença (HEYWOOD, 2010).

Existe uma fronteira entre a esfera pública e a esfera privada. A esfera pública abrange relações políticas e as relações de trabalho, já a esfera privada abrange relações familiares, isola a política das relações de poder da vida cotidiana. Essa divisão sempre causou uma desvantagem de gênero para as mulheres, que tiveram posições impostas a elas, como dedicar-se à família e à vida doméstica, comprometendo sua integridade individual, sendo qualquer comportamento diferente desse padrão, considerado errado. A esfera privada acabou tornando-se um dos meios de dominação masculina, não dizendo respeito ao estado, as mulheres estavam sempre em desvantagem nas relações de poder, também ocultou as comparações entre os papéis ocupados por cada um na esfera pública e na esfera privada (MIGUEL \& BIROLI, 2014).

Para o feminismo, a relação de poder oculta na esfera privada prejudica mais do que apenas esconde parte da vida de cada um, ficam mal-entendidas as posições e relações de poder, além da produção das decisões políticas, sendo assim a visão da esfera pública distorcida. Dessa forma, para construir uma sociedade democrática, é impossível não relacionar as esferas pública e privada, pois os efeitos de uma sempre vão ser sentidos também na outra (MIGUEL \& BIROLI, 2014).

Para Heywood (2010), existem alguns conflitos de pensamento entre as vertentes do feminismo acerca deste assunto. Para o feminismo radical, o pessoal é também o político, ou seja, esta linha separatória não deve existir, pois a opressão existe em todas as partes da sociedade e pode nascer inclusive dentro da família. $\mathrm{O}$ feminismo radical defende a igualdade na divisão de trabalhos domésticos, revendo os papéis masculinos e femininos como um todo, assim como a igualdade na conduta pessoal e sexual de cada um. Quebrar a barreira entre público e privado, seria o mesmo que o Estado ter responsabilidades sobre aspectos da vida privada, como por exemplo oferecer assistência às mães durante seu horário de trabalho (HEYWOOD, 2010). Já o feminismo liberal, embora apoie a inclusão das mulheres na esfera pública, segundo Heywood (2010: 26), "elas também alertam para os perigos da politização 
da esfera privada, que, segundo a teoria liberal, é o âmbito da escolha pessoal e da liberdade individual".

O termo patriarcado representa as relações de poder entre homens e mulheres. Traduzindo, o termo significa "governo do pai" e muitas feministas acreditam que a dominação do pai dentro de casa, significa o domínio masculino em todos os meios: na educação, no trabalho e na política. Sendo assim, a expressão patriarcado costuma ser usada de forma mais geral, abrangendo o domínio masculino não só dentro de casa, mas na sociedade. Entretanto, o conceito de patriarcado é vasto. As mulheres são dominadas pelos homens em boa parte das sociedades, mas a intensidade varia muito entre culturas e épocas diferentes, em muitos lugares do mundo já foram conquistados diversos direitos como acesso à educação, legalização do aborto, maior introdução ao mercado de trabalho, direito à vida com a lei do feminicídio e etc. Porém, em vários outros, o patriarcado ainda se manifesta de forma muito triste, como por exemplo na África onde milhares de mulheres são circuncidadas todos os anos. Tendo um significado amplo, cada vertente do feminismo interpreta o termo patriarcado de formas distintas, mas em um conceito geral, ele simboliza a supremacia masculina em todas as esferas da sociedade (HEYWOOD, 2010).

O patriarcado não passa de um sistema enraizado em nossa sociedade. As pessoas creem nele como uma verdade absoluta e está presente em nosso dia a dia, na forma de atitudes e pensamentos. Segundo Tiburi (2018: 27), "em sua base está a ideia sempre repetida de haver uma identidade natural, dois sexos considerados normais, a diferença entre os gêneros, a superioridade masculina, a inferioridade das mulheres e outros pensamentos que soam bem limitados, mas que ainda são seguidos por muita gente".

Conservadores afirmam que as diferenças de gênero são naturais, pois homens e mulheres possuem naturezas e características diferentes e isso define seus papéis sociais. Ou seja, segundo Heywood (2010: 27), "A constituição física e anatômica da mulher, assim, condiz com um papel subordinado e doméstico na sociedade". A definição da posição social da mulher é diretamente ligada ao fato dela menstruar, poder dar à luz e amamentar, fatores biológicos exclusivamente femininos. Porém estes fatos não devem determinar a posição social de uma mulher, mulheres não precisam arcar com todas as responsabilidades da maternidade sozinhas, pois esta ligação é cultural e não biológica. As tarefas domésticas também devem ser divididas, assim como a criação e educação das crianças, que podem ter influência da sociedade e do Estado (HEYWOOD, 2010).

Ao analisarmos sexo e gênero, existe uma diferença traçada. Sexo são as atribuições femininas e masculinas que fazem parte da natureza e não podem ser alteradas. Já o gênero refere-se aos papéis que a sociedade impõe para homens e mulheres, as diferenças de gênero são impostas baseadas em estereótipos relacionados ao feminino e ao masculino. Não há necessariamente uma ligação entre sexo e gênero, até porque as diferenças de gênero são socialmente as diferenças de sexo entre os homens e mulheres não possuem tamanha relevância que justifique as diferenças de gênero impostas. 
Segundo Heywood (2010: 29), "as diferenças de sexo são fatos biológicos da vida, mas não têm nenhuma relevância social, política ou econômica. Mulheres e homens não devem ser julgados pelo sexo, e sim como indivíduos, como pessoas". $\mathrm{O}$ feminismo busca a conquista e o reconhecimento como indivíduo, sem gênero (HEYWOOD, 2010). Segundo Miguel \& Biroli (2014: 110), "o acesso a recursos e o reconhecimento do valor e da capacidade dos indivíduos para definir a própria vida variam segundo suas características e sua posição nas relações de poder, entre elas o gênero". A desigualdade estrutural delimita as oportunidades de cada pessoa (MIGUEL \& BIROLI, 2014).

O movimento feminista é caracterizado por lutar pelo acesso igual a direitos entre homens e mulheres. Essa luta, abrange muitos pontos importantes, o primeiro deles é a igualdade legal e política, para que as mulheres possam competir na vida pública sem distinção de gênero. Em segundo, acredita-se que direitos iguais só fazem sentido se houver igualdade social, abordando questões como o fim da diferença salarial. Em terceiro, a igualdade na vida pessoal e familiar, que aborda o poder de decisão sobre o próprio corpo, compartilhar de forma igual responsabilidades domésticas e com os filhos, além da satisfação sexual das mulheres. A diferença é associada ao patriarcado e considerada também uma forma de opressão, ou seja, a mulher precisa ser liberta da diferença (HEYWOOD, 2010).

Entretanto, algumas feministas lutam pela diferença, pois tem outra noção sobre a igualdade. Para estas mulheres, lutar pela igualdade é o mesmo que se identificar e querer ser como o homem, o que se torna perigoso por ter de adotar certos comportamentos masculinos. Elas acreditam que mulheres e homens possuem naturezas, genéticas e hormônios diferentes que devem ser levados em consideração e que a libertação se dá quando atinge-se a realização como mulher, devendo enaltecer as características próprias do sexo feminino. Segundo Heywood (2010: 31), “devem buscar a libertação não como "pessoas assexuadas", mas como mulheres evoluídas e realizadas".

Para Miguel \& Biroli (2014), a igualdade é a base para qualquer movimento que defenda grupos oprimidos. No caso do feminismo, sempre foi buscada uma igualdade de direitos entre gêneros, baseado na teoria de que homens e mulheres são iguais em sua capacidade e honestidade, que podem contribuir igualmente para a sociedade. Porém, no final do século XX, surgiu a "política da diferença", que é uma crítica à universalidade, segundo Miguel \& Biroli (2014: 64), "esse discurso que apela a valores universais e à humanidade comum de todas as pessoas, serve, com frequência, para neutralizar a compreensão do impacto que as desigualdades concretas têm sobre a possibilidade de agência autônoma dos diferentes indivíduos". Somente buscar por igualdade não é o suficiente, pois está tentando se inserir em um meio moldado baseado em homens, que possui características masculinas. Devese lutar por diferentes critérios de valorização, características e comportamentos femininos devem ser vistos como tão importantes quanto os masculinos, pois muitas atividades relacionadas aos homens são consideradas mais dignas do que as realizadas 
por mulheres, assim como muitos comportamentos masculinos são naturalizados, enquanto os femininos são tratados como algo particular (MIGUEL \& BIROLI, 2014).

A palavra feminismo tem um impacto forte; enquanto é amada por uns, é odiada por outros. $\mathrm{O}$ feminismo precisa ser pensado, planejado e posto em prática. Segundo Tiburi (2018: 9), "impulsos indignados o movem e, na contramão, outros impulsos também indignados tentam destruí-lo". Para acabar com o ódio que existe acerca do feminismo, sendo grande parte fruto da falta de conhecimento, é preciso fazer com que as pessoas entendam o movimento e principalmente o quanto ele é importante para a sociedade como um todo. O feminismo nos faz repensar a forma como enxergamos o outro e também a nós mesmos, além de auxiliar pessoas a assumirem suas identidades, mesmo que elas não estejam dentro do padrão heteronormativo imposto, sem carregar isso como um sofrimento, sempre defendendo o direito de ser quem somos (TIBURI, 2018).

Cargos de chefia ainda são majoritariamente ocupados por homens, quando uma ideia é dada por uma mulher em uma reunião de negócios, nem sempre é ouvida com tanta importância, mulheres são constantemente julgadas por atitudes que são consideradas normais quando partem de homens, como por exemplo elevar o tom de voz ou expressar raiva. Toda essa desigualdade acaba, inconscientemente, se tornando normal, pois é assim que a sociedade funciona. A mudança em toda essa estrutura deve começar cedo, já na criação dos filhos. É preciso mudar a perspectiva de que meninos devem ser fortes e reprimir suas emoções e que meninas são o sexo frágil, que devem sempre agradar. É preciso educá-los para que sejam seres livres, felizes e construam um mundo diferente (ADICHIE, 2016).

Em relação à mídia, a imprensa feminina é e sempre foi secundária, além de não utilizar muito o jornalismo informativo e distanciar-se bastante da atualidade. Costuma abordar principalmente temas como moda, beleza, culinária, comportamento, etc. E são matérias atemporais, que podem ser utilizadas agora ou daqui alguns anos, o que salienta ainda mais a desconexão com o mundo real (BUITONI, 2009).

Para Ribeiro (2018), ainda vivemos o mito da mulher moderna. Nos anos de 1950, as revistas publicavam donas de casa felizes com seus eletrodomésticos, exaltando uma mulher que cuida da casa. Hoje os eletrodomésticos e tecnologias se atualizaram, as mulheres já estão muito mais dentro do mercado de trabalho, mas no final do dia quando chegam em casa, as tarefas domésticas ainda são papel delas. Podemos ver propagandas que ainda glorificam uma mulher que trabalha fora, cuida da casa, dos filhos, do marido e é feliz. Ou seja, a mentalidade da sociedade ainda não mudou, é apenas mascarada com essa "independência” que foi adquirida pelas mulheres. Segundo Ribeiro (2018: 129), "O mais prejudicial é que se cria a ideia de que ser bem-sucedida é possuir os mesmos direitos que o homem branco, e não romper com as lógicas da opressão. É fazer parte do sistema sem transformá-lo de fato”.

Após as fundamentações teóricas apresentadas para este trabalho, exibe-se, na sequência, a análise dos anúncios da campanha "Highlight the Remarkable". 


\section{Análises: mensagens literais, associadas e declaradas}

Definiu-se para este trabalho, como técnica de análise de dados, os estudos sobre linguagem publicitária de Barthes (2005). Foram analisadas as mensagens literais, associadas e declaradas presentes nas três peças selecionadas. O quadro a seguir sintetiza as respectivas nomenclaturas.

Quadro 1 - Quadro-Síntese da linguagem publicitária

\begin{tabular}{|c|l|}
\hline Literal & $\begin{array}{l}\text { "Imagem ou frase bruta, não polida, reduzida, digamos abstratamente } \\
\text { (para o olhar do analista), às palavras que seriam preciso mobilizar } \\
\text { para poder descrevê-la minimamente”. }\end{array}$ \\
\hline Associada & $\begin{array}{l}\text { "[...] composta por todos os segundos sentidos - às vezes muito } \\
\text { distantes - que eu associo à primeira mensagem, mas que não podem } \\
\text { confundir-se com ela, pois essas associações implicam cultura e } \\
\text { disposições variáveis aos leitores”. }\end{array}$ \\
\hline Declarada & $\begin{array}{l}\text { "[...] é a marca, o próprio produto, cuja menção é a finalidade mesma } \\
\text { da publicidade e cuja presença obrigatória sempre fez do anúncio } \\
\text { publicitário uma comunicação franca”. }\end{array}$ \\
\hline
\end{tabular}

Fonte: Barthes (2005: 104-106)

A campanha selecionada para estudo é a "Highlight de Remarkable", composta por três peças, foi veiculada pela Stabilo, em abril de 2018, na Alemanha e desenvolvida pela DDB Group Germany. A Stabilo é uma marca alemã, que está presente em mais de 180 países e possui mais de 1500 funcionários em sua sede, mas, ainda assim, segue sendo uma empresa familiar, comandada pela família Schwanhäußer há 16o anos. Tem como símbolo um cisne, que é o significado de schwan. A junção das peças se deu através da coleta de anúncios da campanha "Highlight the Remarkable", realizada no site $\mathrm{B}^{2}$. Selecionou-se, para isso, três peças, que representam as personalidades descritas a seguir:

- Edith Wilson: Edith Bolling Galt Wilson foi a segunda esposa do 28o presidente dos Estados Unidos, Woodrow Wilson. Quando Woodrow sofreu um derrame, Edith assumiu o comando até o final de seu segundo mandato ${ }^{3}$.

- Katherine Johnson: Katherine Coleman Goble Johnson, é uma física, cientista espacial e matemática estadunidense. Ela deu contribuições

2 Disponível em: <https://www.b9.com.br/tag/highlight-the-remarkable/>. Acesso em: o1 mai. 2020.

3 Disponível em: <https://www.whitehouse.gov/about-the-white-house/first-ladies/edith-bolling-galtwilson/>. Acesso em: o1 mai. 2020. 
fundamentais para a aeronáutica e exploração espacial dos Estados Unidos, em especial em aplicações da computação na NASA4.

- Lise Meitner: Lise Meitner foi uma física austríaca que estudou radioatividade e física nuclear. Foi a descobridora da fissão nuclear, mas quem recebeu o mérito e um prêmio Nobel foi Otto Hahn, seu parceiro5.

A campanha "Highlight the remarkable" busca dar atenção às mulheres que foram importantes para a história e não tiveram seu devido reconhecimento, o que evidencia o patriarcado que está enraizado em nossa sociedade. Heywood (2010) afirma que o patriarcado representa as relações de poder entre homens e mulheres e há uma dominação masculina em todas as esferas: na educação, no trabalho e na política. Ao abordar um tema como o feminismo, a Stabilo está defendendo uma causa e focando em questões humanas e sociais, o que, segundo Kotler et al., (2010), é o que os consumidores buscam hoje. Eles não olham somente para o produto, mas procuram por marcas que abordem necessidades como essa em sua missão, visão e valores. O consumidor possui uma preocupação maior com a sociedade e uma consciência maior dos efeitos do que consome e apoia.

\section{Edith Wilson}

A primeira peça a ser analisada apresenta uma foto em preto e branco, onde o ex-presidente Woodrow Wilson está de pé, a frente, sorrindo, utilizando terno e chapéu, segurando uma bola de baseball na mão esquerda, como se estivesse prestes a arremessar; seu braço direito está esticado em diagonal para baixo e o punho fechado. Atrás de Woodrow, há várias pessoas sentadas, sendo à sua esquerda, Edith Wilson, que está rindo com uma mão perto da boca, flores à direita de sua roupa e uma boina com um laço na cabeça. A imagem possui bordas grossas abaixo e aos lados da foto, sendo o espaço em cima maior, como se estivesse posicionada na parte central/inferior de uma folha $\mathrm{A}_{4}$ bege.

4 Disponível em: <https://www.nasa.gov/content/katherine-johnson-biography >. Acesso em: or mai. 2020.

5 Disponível em: $<$ http://www.scielo.br/scielo.php?script=sci_arttext\&pid=S1806-111720050004000o1 $>$. Acesso em: o1 mai. 2020. 
Figura 1 - Edith Wilson

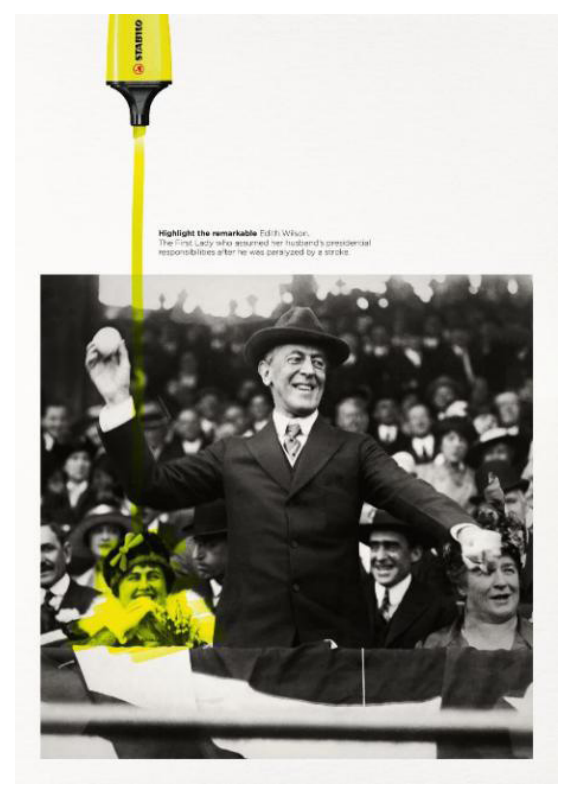

Fonte: site $\mathrm{B}^{6}$

Edith Wilson está pintada de amarelo e dela segue uma linha até a parte superior do anúncio, que sai da ponta de uma caneta marca texto da marca Stabilo. Só uma parte da caneta está amostra, é retangular, amarela e possui um detalhe perto da ponta em preto. A marca Stabilo aparece escrita na horizontal da caneta e em preto, ao lado da palavra está o logo, que é um cisne dentro de um círculo, em vermelho.

Logo acima da imagem, à direita da linha de marca texto, há um pequeno texto escrito com uma fonte fina e preta, quebrado em três linhas curtas. A primeira linha contém as três primeiras palavras em negrito e diz "Highlight the remarkable Edith Wilson", a segunda linha diz "the first lady who assumed her husband's presidential", e a terceira "responsibilities after he was paralyzed by a stroke.". Traduzindo o texto, a mensagem significa "Grife o inesquecível. Edith Wilson, a primeira mulher a assumir as responsabilidades presidenciais, após seu marido sofrer um derrame”.

Analisando a peça acima, fica claro, por ser a primeira mulher na função, que quando Edith Wilson assumiu as responsabilidades presidenciais do marido, em 1919, não era normal que mulheres fizessem parte da política. Um dos pontos do feminismo segundo Heywood (2010), é lutar pela igualdade entre homens e mulheres, abrangendo pontos importantes, sendo o primeiro deles a igualdade legal e política, para que as mulheres possam competir na vida política sem distinção de gênero. Nesse caso, não haveria como Edith ser eleita, pois não era permitido que mulheres se candidatassem e nem ao menos votassem. O direito ao voto só foi conquistado em 1932 e para Heywood (2010) uma das maiores lutas do movimento feminista foi a campanha pelo sufrágio feminino, ou seja, o direito de votar. As mulheres

6 Disponível em: <https://www.b9.com.br/93552/Stabilo-chama-a-atencao-da-internet-com-propagandaque-marca-as-mulheres-invisiveis-da-historia/>. Acesso em: o8 mai. 2020. 
acreditavam que se tivessem direito ao voto, a discriminação e o preconceito sexual também acabariam. Esse período foi chamado de "primeira onda" e foi definido pela busca dos mesmos direitos legais e políticos que os homens já obtinham.

A proposta que é transmitida ao defender uma causa como o feminismo, que é um movimento social, político e econômico, é mostrar o posicionamento da marca e sua preocupação com as crenças dos clientes. Isso, segundo Kotler et al., (2010), passou a ser o centro, pois hoje o valor da marca é determinado pelo cliente, sendo antes focado no produto e no consumidor, hoje vemos uma atenção maior principalmente às questões humanas. Além disso, também afirmam que com os avanços da tecnologia e redes sociais, os consumidores começaram a se expressar com maior facilidade e com isso compartilhar suas opiniões e experiências, o que influencia outros consumidores e diminui o impacto da propaganda corporativa. Este tipo de posicionamento da marca gera comoção e costuma ser muito comentado, além de fazer com que os clientes criem uma identificação maior, criando assim uma relação com a marca, o que é de extrema importância. Conforme afirma Kotler (2003), é necessário criar uma relação com o consumidor, onde a ideia não é que comprem somente uma vez, mas que haja um consumo contínuo, captando assim clientes para a empresa.

Ao observar Edith em segundo plano e Woodrow destacando-se à frente, também podemos refletir sobre a sociedade desigual em que vivemos, onde homens sempre estão em posições e cargos de poder à frente das mulheres, o que confirma o que dizem Miguel \& Biroli (2014), que a desigualdade de gênero sempre foi uma realidade no mundo inteiro e este fato nunca foi algo oculto, mas, sim, tratado com normalidade, como se fosse algo natural devido à natureza diferenciada dos homens e mulheres. E embora ouçamos que isso já foi superado devido à alguns avanços já conquistados, continuamos em uma sociedade desigual que segue desconsiderando que existe uma igualdade intelectual e moral e deixa as mulheres em desvantagem, sendo a conservação da dominação masculina ainda muito forte e notável; o que também complementa a ideia de Heywood (2010), de que o patriarcado engloba o domínio masculino não só dentro de casa, mas na sociedade. E mesmo possuindo um amplo significado, interpretado de diferentes formas entre as vertentes do feminismo, de modo geral, ele representa o domínio masculino em todos os âmbitos em que vivemos.

A peça também desperta implicitamente uma reflexão sobre a importância de se debater o feminismo nos dias atuais, principalmente por se tratar de um movimento que gera muita polêmica e opiniões controvérsias. Tiburi (2018) sinaliza que grande parte dessa aversão que o feminismo gera, é fruto da falta de conhecimento. É necessário fazer com que as pessoas entendam o movimento e o real tamanho da sua importância, não somente para as mulheres, mas para a sociedade como um todo. $\mathrm{O}$ feminismo nos faz reconsiderar a forma como percebemos a nós mesmo e também aos outros, além de ajudar as pessoas a assumirem suas identidades, mesmo que não estejam dentro de algum determinado padrão que a sociedade impõe, sem carregar isso como um sofrimento, sempre defendendo o direito de ser quem somos. Com isso, 
também, podemos constatar que a marca assume um certo risco ao abordar o tema, podendo ter reações positivas ou negativas por parte dos consumidores. Segundo Kotler \& Keller (2013), se a reação for positiva, a marca terá brand equity positivo baseado no cliente. Para alcançar um brand equity positivo, a marca precisa criar associações fortes e únicas de ideias, imagens, pensamentos e experiências, para que as pessoas reconheçam a marca e optem pela mesma. Tudo isso deve ser criado e transmitido de forma clara e sincera, conforme afirmam Kotler et al., (2010), não se deve nutrir uma realidade falsa somente para a propaganda, a empresa precisa ser verdadeira ao transmitir algo para seu público, ou acabam por perder a credibilidade, e consequentemente, seus compradores.

Quanto a mensagem declarada, temos presente na peça um produto clássico da marca, que é a caneta marca texto amarela com o nome e logo da Stabilo gravados nela, o fato da marca ser mundialmente reconhecida também é um ponto positivo para atrair o interesse do consumidor ao anúncio, pois segundo Martins (2000), as marcas são extremamente valorizadas durante a decisão de compra dos brasileiros.

Além de estar em destaque no alto da peça, são os únicos ícones presentes que apresentam cor, chamando ainda mais a atenção do consumidor. A evidência da marca é importante, pois a peça aborda o reconhecimento das mulheres, que é uma causa que gera associações positivas para ela. E segundo afirmam Crescitelli \& Shimp (2012), é preciso estabelecer uma identidade positiva e criar associações positivas e marcantes da marca na mente do consumidor, a fim de promover seu valor. Além disso, podemos resgatar o que dizem Kotler et al., (2010), que para construir uma relação com o consumidor, a marca deve assumir um posicionamento, um DNA singular que a diferencie. Esse DNA é um dos maiores desafios do marketing e deve ser o que caracteriza a marca nas redes sociais e também na comunicação com o público. Outro ponto positivo de haver um produto com o logo em destaque no anúncio, é que isso fortalece a percepção da marca, que para Crescitelli \& Shimp (2012), significa o quanto a marca é conhecida, ou seja, a percepção da marca está no fato de os consumidores recordarem dela ou não quando falam de produtos que a mesma oferece.

\section{Katherine Johnson}

A segunda peça a ser analisada apresenta uma foto em preto e branco, onde podemos ver o centro de controle da Nasa. Uma sala grande com muitos corredores de painéis operacionais e muitas pessoas entre eles; de todas as pessoas que podemos ver nitidamente, praticamente todos são homens e vestem camisas sociais ou ternos e gravatas, entre eles há apenas uma mulher que veste preto. Muito ao fundo, no lado direito, está Katherine Johnson, onde dificilmente pode-se identificá-la. 
Figura 2 - Katherine Johnson

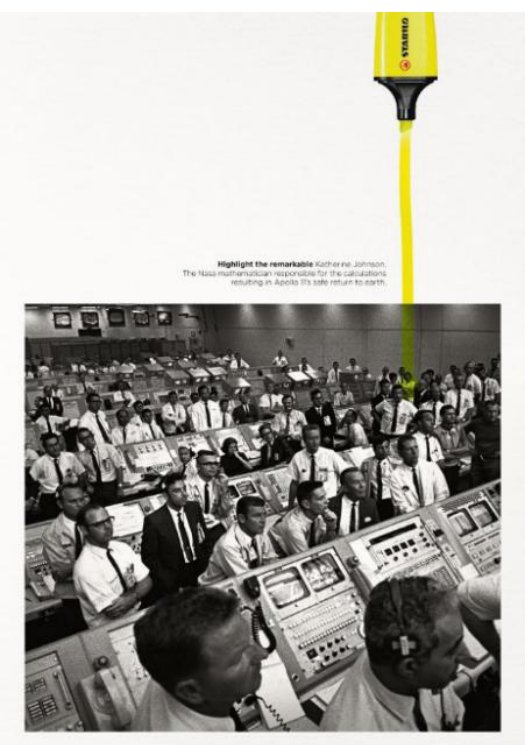

Fonte: site $\mathrm{B}^{7}$

A imagem, como na peça anterior, possui bordas grossas abaixo e aos lados da foto, sendo o espaço em cima maior, como se estivesse posicionada na parte central/ inferior de uma folha $\mathrm{A}_{4}$ bege. Katherine Johnson está à direita da imagem pintada de amarelo e dela segue uma linha até a parte superior do anúncio, que sai da ponta de uma caneta marca texto da marca Stabilo. A caneta tem só uma parte à mostra, é retangular, amarela também com um detalhe perto da ponta em preto, nela está o escrito Stabilo na horizontal em preto e ao lado da palavra, está o logo que é um cisne dentro de um círculo, em vermelho.

Logo acima da imagem, à esquerda da linha de marca texto, há um pequeno texto escrito com uma fonte fina e preta, quebrado em três linhas curtas. A primeira linha contém as três primeiras palavras em negrito e diz "Highlight the remarkable Katherine Johnson", a segunda linha diz "The Nasa mathematician responsible for the calculations", e a terceira “resulting in Apollo 11's safe return to earth.". Em português, a mensagem significa "Grife o inesquecível. Katherine Johnson, a matemática da Nasa responsável pelos cálculos que resultaram no retorno seguro do Apollo 11 à terra”.

Analisando a peça acima, pode-se concluir que a campanha não busca trabalhar benefícios do produto, mas sim benefícios de auto expressão. Segundo Bedendo (2015), os benefícios não precisam ser diretamente ligados ao produto, podem ser também emocionais, funcionais ou de auto expressão, mas é necessário criar algo que se destaque, um diferencial que seja atribuído fortemente a marca. Ainda conforme afirma Bedendo (2015), com a popularização das redes sociais, é dada cada vez mais importância a isso, o consumidor cria uma ligação maior com a marca, pois estes benefícios estão diretamente relacionados à personalidade, então a

7 Disponível em: <https://www.b9.com.br/93552/Stabilo-chama-a-atencao-da-internet-com-propagandaque-marca-as-mulheres-invisiveis-da-historia/>. Acesso em: 08 mai. 2020. 
imagem da marca passa a ser utilizada para se expressar, os consumidores a utilizam para representar o que querem transmitir. Ou seja, as marcas devem planejar o que querem comunicar e como querem ser vistas, para conseguir alcançar o público que desejam.

A partir desse ponto, podemos afirmar que busca-se promover o valor de marca e criar associações positivas, resgatando o que afirmam Crescitelli \& Schimp (2012), de que devem ser criadas relações fortes e positivas da marca na mente do consumidor, para promover seu valor. Além disso, é necessário um trabalho constante de marketing, pois não é possível criar uma imagem positiva de um dia para o outro.

Analisando a imagem presente na peça, podemos ver uma diferença irrefutável entre o número de mulheres e homens presentes, o que evidencia a falta de igualdade presente no meio profissional. Segundo Heywood (2010), a diferença é também uma forma de opressão e está diretamente ligada ao patriarcado. A mulher precisa libertar-se da diferença, pois acredita-se que para que direitos iguais façam sentido, é necessário haver igualdade social também, o que reflete em questões como o fim da diferença salarial e da desigualdade nas posições dentro do mercado de trabalho, onde mulheres ainda são minoria.

Além disso, fica evidente que mesmo Katherine tendo sido a matemática responsável pelos cálculos que resultaram no retorno seguro do Apollo 11 à Terra, ela não recebeu reconhecimento por isso. Conforme afirma Heywood (2010), o feminismo possui dois conceitos fundamentais: o de que as mulheres vivem em uma posição de inferioridade pelo simples fato de serem mulheres e de que essa inferioridade deve deixar de existir. Complementando Heywood (2010), Miguel \& Biroli (2014) afirmam que a igualdade é o princípio básico em todos os movimentos que defendem grupos oprimidos. O feminismo defende que homens e mulheres podem contribuir igualmente para a sociedade, pois são similares em sua capacidade e integridade, a partir disso busca-se a igualdade de direitos entre os gêneros. Miguel \& Biroli (2014), também defendem que a sociedade e o meio em que se está tentando se inserir, possuem características masculinas, foram construídos baseados em homens, sendo assim, buscar somente pela igualdade não é o suficiente. Um exemplo disso, é o fato de que comportamentos masculinos são naturalizados, ao passo que os femininos são vistos como algo particular, sendo as muitas atividades realizadas por homens consideradas mais dignas do que as realizadas por mulheres, ou seja, os critérios de reconhecimento devem mudar, buscando-se assim uma valorização do comportamento e características femininas.

A peça apresentada, também, deixa claro que a marca está assumindo um posicionamento forte, lutando a favor de uma causa, o que pode gerar um diferencial em relação à concorrência. Segundo Wheeler (2009), a identidade da marca é o que gera reconhecimento e traz singularidade. O branding é um modo de fazer com que as pessoas compreendam a marca, aproveitando-se assim todas as oportunidades de evidenciar o diferencial e o motivo porque a marca deve ser escolhida ao invés das outras, buscando a fidelidade dos clientes. 
Ainda analisando a foto presente na peça, podemos notar que não era comum ver mulheres nos escritórios e ambientes profissionais, podendo refletir sobre como as diferenças naturais entre homens e mulheres são levadas em consideração na hora de definir seus papéis sociais. Segundo Heywood (2010), a sociedade determina a posição social da mulher de acordo com fatores biológicos exclusivamente femininos, como dar à luz e amamentar, o que implica em um papel subordinado e doméstico. Quando na verdade, as responsabilidades domésticas e maternas devem ser distribuídas igualmente entre homens e mulheres, essa associação de que a mulher deve ser a responsável é apenas cultural e não biológica. Além disso, Heywood (2010) ainda afirma que mulheres e homens devem ser julgados apenas como indivíduos, não pelo sexo, afinal as diferenças de sexo não devem ter nenhuma relevância social, política ou econômica, pois são apenas fatos biológicos da vida. $\mathrm{O}$ feminismo busca o reconhecimento do indivíduo, sem distinção de gênero. Ainda podemos complementar com a afirmação de Miguel \& Biroli (2014), de que a desigualdade estrutural define as oportunidades de cada pessoa, pois o acesso a recursos e a valorização da capacidade de cada um variam de acordo com suas características e sua colocação nas relações de poder, entre elas o gênero.

Assim como na peça anterior, podemos ver um produto da marca, que é o marca-texto amarelo com o nome e logo da Stabilo gravados nele, sendo o nome em preto e o logo em vermelho. São também os únicos elementos presentes que possuem cor. A marca em destaque na peça cria uma recordação para o consumidor e reforça a sua identidade de forma positiva, segundo Bedendo (2015), a identidade é a alma da marca. É preciso assumir características e criar um conteúdo atrativo para o consumidor, que mostrem como ela quer ser percebida, fazendo com que ele crie uma identificação e sinta-se próximo da marca.

Além disso, também é preciso criar relações e lembranças (que podem ser afetadas pela experiência do consumidor). As associações de marca podem ser trabalhadas de inúmeras formas, imagens, elementos, cores, experiências, etc. E devem ser criadas e controladas de acordo com o que a marca deseja transmitir. Além disso, o logo realçado junto do produto gera reconhecimento, contribuindo para que a marca seja lembrada. Conforme afirmam Crescitelli \& Shimp (2012), os consumidores podem conseguir identificar uma marca no meio de uma lista ou sugestões, porém um número bem menor é capaz de lembrar do nome de uma marca sem nenhum lembrete. Por isso, existe um caminho que a comunicação de marketing deve seguir, que é: tornar a marca conhecida, conquistar o reconhecimento, buscar a recordação de marca e, por fim, manter um nível alto de percepção para alcançar o top of mind, o que significa que a marca é a primeira que vem à mente quando os consumidores pensam a respeito. 


\section{Lise Meitner}

A terceira e última peça a ser analisada apresenta uma foto em preto e branco, onde vemos três homens bem vestidos, de terno, sentados em torno de uma mesa quadrada, que está aparecendo pela metade no canto inferior direito da imagem. A mesa possui diversas louças como pratos e xícaras espalhados por sua extensão. Entre os homens sentados ao meio e à direita, há um homem em pé que também veste terno. Já atrás dos homens sentados ao meio e à esquerda da foto, podemos ver duas mulheres também em pé, a mulher a esquerda usa um vestido claro e é um pouco mais alta. A mulher que está à direita é Lise Meitner e usa um vestido escuro com detalhes claros no colo, ambas estão usando chapéus. Ao fundo da imagem podemos ver árvores e folhagens.

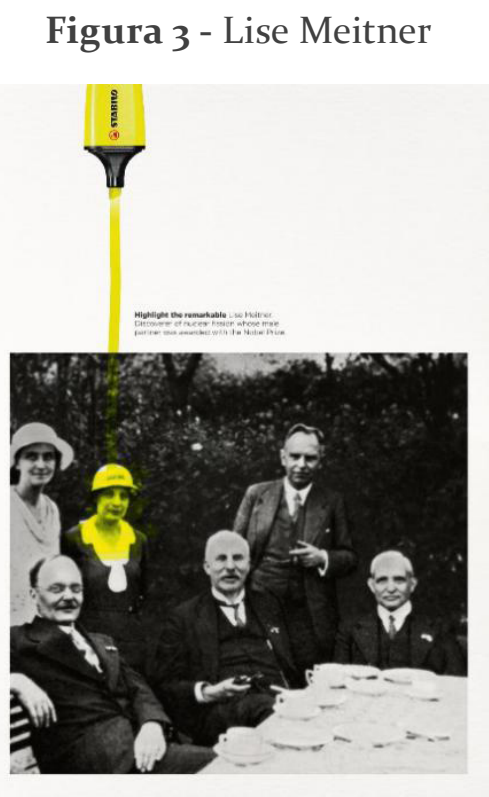

Mantendo o padrão já apresentado nas peças anteriores, a imagem possui bordas grossas abaixo e aos lados da foto, sendo o espaço em cima maior, como se estivesse posicionada na parte central/inferior de uma folha $\mathrm{A}_{4}$ bege. Lise Meitner está pintada de amarelo e dela segue uma linha até a parte superior do anúncio, que sai da ponta de uma caneta marca texto da marca Stabilo. A caneta tem só uma parte à mostra, é retangular, amarela também com um detalhe perto da ponta em preto, nela está escrito Stabilo na horizontal em preto e ao lado da palavra, está o logo que é um cisne dentro de um círculo, em vermelho.

Logo acima da imagem, à direita da linha de marca texto, há um pequeno texto escrito com uma fonte fina e preta, quebrado em três linhas curtas. A primeira linha diz contém as três primeiras palavras em negrito e diz "Highlight the remarkable Lise

8 Disponível em: <https://www.b9.com.br/93552/Stabilo-chama-a-atencao-da-internet-com-propagandaque-marca-as-mulheres-invisiveis-da-historia/>. Acesso em: o8 mai. 2020. 
Meitner", a segunda linha diz "Discoverer of nuclear fission whose male", e a terceira "partner was awarded with the Nobel Prize.". Em português, a mensagem significa "Grife o inesquecível Lise Meitner, descobridora da fissão nuclear, cujo parceiro masculino foi premiado com o Prêmio Nobel”.

Analisando a terceira peça e o fato apresentado de que o parceiro de Lise recebeu o Prêmio Nobel pela sua descoberta, podemos refletir sobre a desvalorização da mulher e de sua capacidade intelectual, pelo simples fato dela ser mulher. Tiburi (2018) afirma que o patriarcado é constituído por diversas ideias, como por exemplo a superioridade masculina, de haver uma identidade natural, dois sexos que são considerados normais, a inferioridade feminina, diferença entre os gêneros, etc. É um sistema de pensamentos limitados que está entranhado em nossa sociedade e presente no dia a dia, em forma de atitudes e pensamentos. As pessoas ainda o seguem e acreditam nele como uma verdade absoluta. Outro ponto que podemos abordar a partir da desvalorização intelectual da mulher, é em relação a mídia que é criada destinada ao público feminino. Para Buitoni (2009), além de distanciarse muito da realidade e não empregar muito o jornalismo informativo, a imprensa feminina está e sempre esteve em segundo plano, abordando principalmente temas como moda, beleza, culinária, comportamento, etc. Sendo ainda matérias atemporais, com exceção da moda que se atualiza com mais frequência, são coisas que podem ser utilizadas agora ou daqui alguns anos, enfatizando mais ainda a desconexão com o mundo real.

A peça acima transmite a preocupação e empatia que a marca tem para com causas sociais e humanas, construindco assim uma relação mais próxima com o público e gerando valor para a marca. Para Kotler et al., (2010), muito além de oferecer ao cliente satisfação e uma boa performance do produto, a marca deve praticar compaixão e realizar aspirações emocionais. Ou seja, o marketing deixa de ser apenas uma ferramenta de vendas, para se tornar uma junção de identidade, integridade e imagem, deve criar uma relação com o consumidor e conquistar sua confiança. Bedendo (2015) ainda afirma que as empresas passaram a compreender a importância do valor de marca. Os métodos de gestão e tecnologias estão evoluindo cada vez mais para entender o público e suas necessidades. Além disso, não existe uma regra quando trata-se de criar valor de marca, pois está lidando-se com paixão, o que pode ser muito instável, mas também uma enorme oportunidade, se isso for transmitido para o cliente com uma comunicação apropriada.

Podemos enfatizar, que a marca busca promover um diferencial, reafirmar sua identidade e criar associações positivas que vão se fixar na mente do consumidor. Segundo Guillermo (2012), a identidade de marca é imprescindível para se destacar, dado o fato de que estamos cada vez mais parecidos com os outros, é uma forma de mostrar singularidade e expor a marca de uma forma que ninguém nunca viu, e é importante sempre fazer isso de forma honesta e transparente. Pondo isto em prática, é necessário criar uma estratégia de marca. Para chegar ao objetivo traçado, deve-se idealizar e desenvolver ações que englobem planejamento de marca, mídia, 
comunicação, etc. Isto é, todos os diferentes setores e profissionais devem trabalhar juntos e voltados para o mesmo ponto.

Além disso, a estratégia de marca preserva a identidade e mostra planos futuros, potencial crescimento e longevidade, o que pode atrair acionistas e franqueados, pois gera confiança para que invistam na marca. Ainda refletindo sobre o fato de Lise não ter recebido o reconhecimento por sua tão importante descoberta, vemos como homens são tratados com maior seriedade e respeito no meio profissional e social, o que resgata a afirmação de Adichie (2016), de que homens ainda ocupam a grande maioria dos cargos de chefia e tem suas ideias ouvidas com muito mais importância em reuniões de negócios, atitudes consideradas normais quando partem de homens, como expressar raiva ou elevar o tom de voz, são frequentemente julgadas de forma negativa quando vem de mulheres. E toda essa desigualdade é, mesmo que inconscientemente, naturalizada, pois a sociedade funciona assim. Para termos uma mudança nesses padrões, é preciso começar desde cedo, na educação. É preciso mudar a concepção de que meninos não devem expressar emoções pois devem ser fortes, enquanto meninas são o sexo frágil, que precisa sempre agradar. É preciso educar para que sejam seres felizes, individuais e livres, ensiná-los a construir um mundo diferente.

Além disso, a peça leva a pensar no cenário atual da mulher. Hoje as mulheres estão mais inseridas no mercado de trabalho, além de terem conquistado diversos direitos, mas ainda assim, existem diversas tarefas que seguem sendo socialmente associadas à mulher. Para Ribeiro (2018), seguimos vivendo o mito da mulher moderna. Em meados de 1950, revistas costumavam retratar a mulher como dona de casa, feliz com seus eletrodomésticos, evidenciando uma mulher que cuida da casa. Hoje a imagem mudou um pouco, os eletrodomésticos e tecnologias se atualizaram, mulheres estão muito mais presentes no mercado de trabalho, mas as tarefas domésticas continuam fazendo parte do seu papel. As propagandas mudaram, mas ainda exaltam a mulher que trabalha, cuida da casa, dos filhos, do marido e é feliz. Ou seja, a "independência" adquirida pelas mulheres ajuda a esconder o fato de que a mentalidade da sociedade ainda não mudou. É criada a ideia de que ser bemsucedida significa ter os mesmos direitos que o homem branco, o que é prejudicial e não combate as lógicas de opressão, é o mesmo que fazer parte do sistema sem transformá-lo.

Assim como citado e visto acima, podemos ver presente no alto peça a caneta marca texto amarela da marca, onde está escrito o nome da Stabilo em preto e seu logo em vermelho, mantendo um padrão em toda a campanha. São os únicos itens que possuem cor, sendo assim, ficam em destaque. O destaque para o nome e logo são importantes, considerando que a marca deve sempre estar em evidência pois é um dos principais pontos desde a sua criação, para Guillermo (2012), o nome e o logotipo são uma das primeiras coisas a se definir quando se inicia uma empresa, embora ainda não sejam todos que deem a importância necessária a isso, com o tempo e amadurecimento acabam percebendo que é preciso dar atenção e investir nessa parte. Complementando Guillermo (2012), Kotler \& Keller (2013), afirmam que marca 
deve destacar-se, criar um diferencial em relação à concorrência e gerar uma reação diferente no cliente. É preciso trabalhar ideias, imagens, pensamentos e experiências que criem ligações fortes e exclusivas, para alcançar o reconhecimento e preferência pela marca. Tais ligações foram trabalhadas na peça ao relacionar a marca com uma causa social, o que gera uma reação positiva, além de criar uma relação e aproximá-la de seus consumidores. Bedendo (2015) ainda afirma que a marca pode modificar ou evoluir sua forma de se comunicar, alterando características e comportamentos, de modo que se adapte ao que for preciso, porém mantendo seus valores e convicções sempre alinhados, pois são a essência da marca.

\section{Considerações finais}

Apesar do feminismo ser um movimento que está em evidência atualmente, percebemos que ainda é um assunto que precisa ser muito explorado e debatido. Apesar de todas as evoluções que já foram conquistadas, a sociedade ainda não mudou seus moldes e podemos ver que a desigualdade e o patriarcado continuam extremamente presentes em sua raiz. Mesmo que inconscientemente, reproduzimos falas e atitudes que confirmam o sistema de opressão em que estamos inseridos. É necessário uma conscientização e desconstrução dessa situação, para que seja possível conquistar a igualdade entre os gêneros e o espaço das mulheres na sociedade.

Por muito tempo, o feminismo foi um assunto invisível na mídia. O conteúdo produzido para as mulheres sempre foi relacionado a coisas ligadas a casa ou assuntos banais; sua imagem sempre foi vendida como um 'produto', além de ter um padrão de corpo perfeito imposto. Felizmente, com a popularização do movimento, ele vem ganhando espaço. Algumas marcas vêm abordando o feminismo com maior frequência em sua comunicação, porém, nem todas assumem uma posição direta, como a Stabilo apresentou na campanha analisada, mas estão começando a retratar a mulher de forma real, ou seja, aos poucos a imagem da mulher tem começado a mudar.

Não se deve esquecer que, além da mudança na mídia, é necessário haver uma mudança também dentro das empresas, onde as mulheres possam ocupar cargos de poder, gerando, assim, representatividade e coerência com o que é defendido. A Stabilo buscou dar o devido reconhecimento a essas mulheres e seus feitos que foram tão importantes para a atual sociedade. Espera-se, entretanto, que campanhas como a "Highlight the Remarkable" da Stabilo sejam, cada vez mais, frequentes e constantes na publicidade mundial. 


\section{Referências}

ADICHIE, Chimamanda Ngozi. (2016) Sejamos todos Feministas. São Paulo, SP: Companhia das Letras.

BARTHES, Roland. (2005). Inéditos. 1. ed São Paulo, SP: Martins Fontes.

BEDENDO, Marcos. (2015). Branding para Empreendedores: Ferramentas práticas para criar sua marca potencializando o sucesso do seu negócio. São Paulo, SP: M. Books.

BUITONI, Dulcília Schroeder. (2009). Mulher de Papel: a representação da mulher pela imprensa feminina brasileira. São Paulo, SP: Summus.

CRESCITELLI, Edson; SHIMP, Terence A. (2012). Comunicação de Marketing: integrando propaganda, promoção e outras formas de divulgação. São Paulo, SP: Cengage Learning.

GUILLERMO, Alvaro. (2012). Branding: design e estratégias de marca. São Paulo, SP: Brooklin, 2012.

HEYWOOD, Andrew. (2010). Ideologias Políticas: do feminismo ao multiculturalismo. São Paulo, SP: Ática.

KOTLER, Philip. (2003). Marketing de A a Z: 8 o conceitos que todo profissional precisa saber. Rio de Janeiro, RJ: Elsevier.

KOTLER, Philip; KARTAJAYA, Hermawan; SETIAWAN, Iwan. (2010). Marketing 3.o: as forças que estão definindo o novo marketing centrado no ser humano. Rio de Janeiro, RJ: Elsevier.

KOTLER, Phillip; KELLER, Kevin. (2013). Marketing Essencial: conceitos, estratégias e casos. São Paulo, SP: Pearson Education do Brasil.

MARTINS, José Roberto. (2000). Branding: um manual para você criar, gerenciar e avaliar marcas. São Paulo, SP: Negócio Editora.

MIGUEL, Luis Felipe; BIROLI, Flávia. (2014). Feminismo e Política. São Paulo, SP: Boitempo Editorial.

RIBEIRO, Djamila. (2018). Quem tem medo do feminismo negro? São Paulo, SP: Companhia das Letras. 
TIBURI, Marcia. (2018). Feminismo em comum: para todas, todes e todos. Rio de Janeiro, RJ: Rosa dos Tempos.

WHEELER, Aline. (2009). Design de Identidade da Marca: guia essencial para toda a equipe de gestão de marcas. São Paulo, SP: Bookman.

Recebido em 08/o8/2019.

Aceito em 20/03/2020. 